\title{
Effect of Two Harvesting Systems on the Yield and Seed Percentage of Snap Beans, Phaseolus vulgaris, in the Isabela Area ${ }^{1}$
}

\author{
Gerardo Mangual Crespo ${ }^{2}$
}

\begin{abstract}
Optimum marketable yields of $5,560,3,991$, and $5,672 \mathrm{~kg} / \mathrm{ha}$ were obtained when snap bean variety Wade was harvested using the once-over system, at 55 days; Tendergreen at 49 days, and Contender at 47 days, respectively. In the multiple harvesting system, marketable yields of Wade, Tendergreen, and Contender were of the order of $5,381,3,632$, and $6,995 \mathrm{~kg} /$ ha in two, three, and two pickings, respectively. Mean differences were not significant. The once-over harvesting system should be preferred because production costs are lower.
\end{abstract}

\section{INTRODUCTION}

Snap bean harvesting in Puerto Rico is traditionally a manual operation requiring much labor and reducing the possibilities of providing a reasonable income to farmers. The demand for this crop is fairly high; imports for 1974-75 amounted to 3,830 tons, mostly of the processed product, with a wholesale value of $\$ 1,900,000 .^{3}$

Harvesting is usually at irregular intervals, generally every 7 days, depending on the availability of hand labor and climatic conditions. This practice adversely affects the quality of the pods which usually harden and become fibrous when harvesting is delayed.

In the United States, the bush snap bean is harvested by using a onceover mechanized system when pods attain optimum development.

Seed percentage is considered to be an important criterion in determining pod quality. When comparing yields, it is desirable that the seed percentage of the different varieties be within a similar range.

\section{MATERIALS AND METHODS}

An autumn planting (September 19, 1975) was made on a Coto clay, an Oxisol, at the Isabela Agricultural Experiment Substation.

The objective of the experiment was to determine the effect on yields of two systems of harvesting snap beans (once-over harvest vs. multiple harvests at weekly intervals).

${ }^{1}$ Manuscript submitted to Editorial Board May 26, 1976.

${ }^{2}$ Research Assistant, Agricultural Experiment Station, Mayagüez Campus, University of Puerto Rico, Río Piedras, P.R.

${ }^{3}$ Boletín Mensual de Estadísticas Agrícolas de P.R. Oficina de Estadísticas Agrícolas, Departamento de Agricultura. 15(4): 165, abril, 1975. 
A split plot design with four replications was used. Three commercial varieties (Wade, Tendergreen, and Contender) were the main plots, and harvesting methods were the subplots. Seed was sown by hand at approximately $8 \mathrm{~cm}$ apart in rows $90 \mathrm{~cm}$ apart and $6 \mathrm{~m}$ long. Dacthal $75 \mathrm{~W}^{4}$ was applied as a pre-emergent herbicide immediately after planting at the rate of $11.25 \mathrm{~kg}$ of active ingredient/ha. Overhead irrigation was applied twice during the first week and once weekly afterwards, until flowering. Furrow irrigation was used as necessary. A weekly preventive spraying program was followed, mixing Diazinon AG500 and Dithane M-45 at the rate of $120 \mathrm{ml}$ and $2.25 \mathrm{~kg} / \mathrm{ha}$, respectively, to control damage by insects and diseases.

For testing the optimum date of harvesting in the once-over system the corresponding plots were harvested at 2-day intervals starting at 43 days after planting and ending at 65 days. Pods were harvested from all plants and classified into marketable pods and culls.

In the multiple harvest system, plots were harvested weekly, beginning at 43 and ending at 64 days after planting. Pods were harvested selectively using the same criteria as for the other system.

Attempts were made to harvest the varieties at an early stage of seed development, which corresponds to grade A of the U.S. standards for fresh snap beans. The seed content at this stage was judged to be below $8 \% .^{5}$

\section{RESULTS AND DISCUSSION}

There were no significant differences in total and marketable yields between harvesting systems. Yields obtained from the once-over system compared favorably with those of previous plantings. ${ }^{6}$

Although four pickings were made from the three varieties in the multiple harvest system, marketable yields from Wade were obtained in only two of them; the best yield was obtained 50 days after planting $(2,982 \mathrm{~kg} / \mathrm{ha}) ; 57$ days after planting, $2,399 \mathrm{~kg} / \mathrm{ha}$ were obtained for a total marketable yield of $5,381 \mathrm{~kg} / \mathrm{ha}$.

Marketable yields of Tendergreen in the first three pickings were $1,166,1,861$ and $605 \mathrm{~kg} / \mathrm{ha}$, respectively, for a total marketable yield of $3,632 \mathrm{~kg} / \mathrm{ha}$. Marketable yields of Contender were 3,632 and 3,363 kg/ha

${ }^{4}$ Trade names are used in this publication solely for the purpose of providing specific information. Mention of a trade name does not constitute a guarantee or warranty of equipment or materials by the Agricultural Experiment Station of the University of Puerto Rico or an endorsement over other equipment or materials not mentioned.

${ }^{5}$ Kramer, A., Twigg, B. A., Application of Statistical Quality Control Procedures to the Canning of Green Beans, Univ. Md., College Park, Md., May, 1957.

"Mangual-Crespo, G., Effect of time of planting on the marketable yield of two snapbean varieties at Isabela, Puerto Rico. J. Agric. Univ. P.R. 59(3): 219-21, 1975. 
in the first and second pickings, respectively, for a total yield of $6,995 \mathrm{~kg}$ / ha (fig. 1).

In the multiple harvest system, the total and marketable yields obtained, disregarding varieties, were more or less similar to those from the once-over harvesting system, i.e., 7,376 and 5,336 vs. 6,494 and 5,074 $\mathrm{kg} / \mathrm{ha}$, respectively. Differences between harvesting systems were not significant for any particular variety.

This study confirms that there are differences in varietal yield patterns possibly attributable to individual responses to environmental

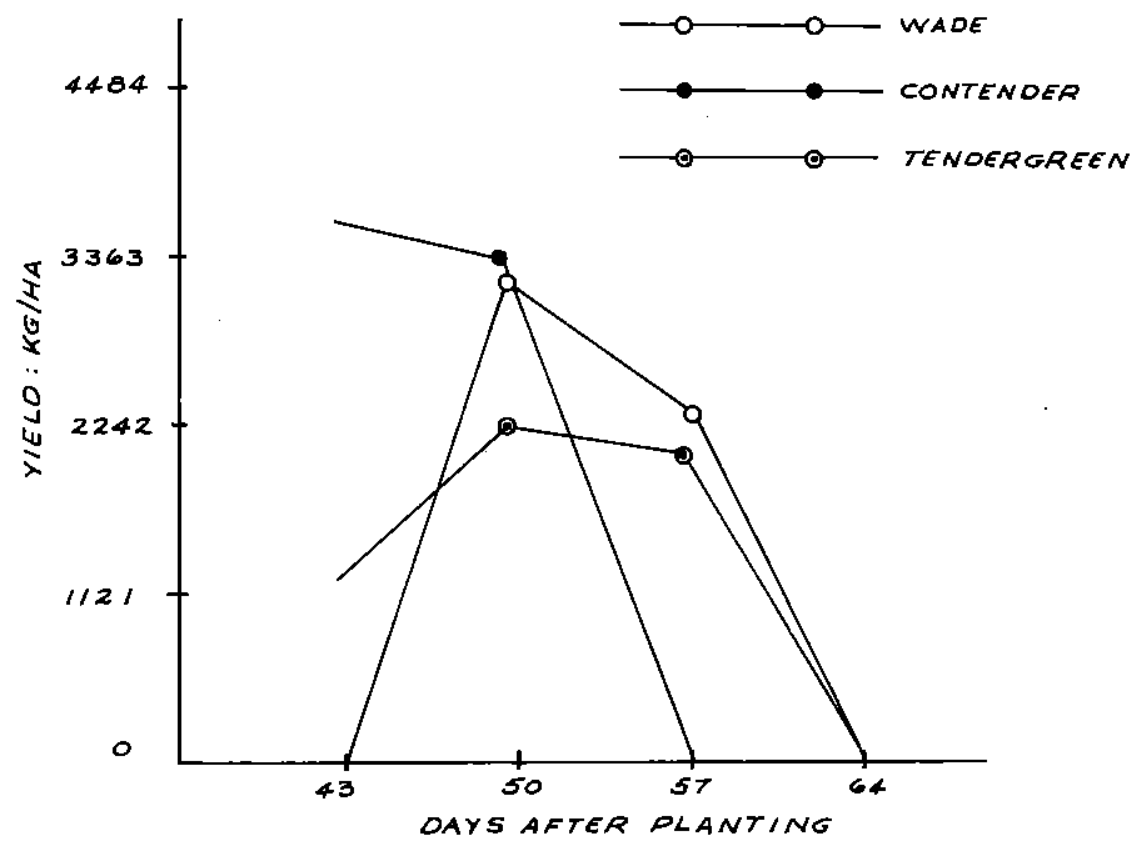

Fig. 1.-Marketable yield of three snapbean varieties in the multiple harvesting system.

changes. There were no significant differences in the marketable and total yields of Wade and Contender; however, these two varieties outyielded Tendergreen significantly at the 5\% level in both harvesting systems. In the once-over harvesting system, seed percentages of varieties Tendergreen and Contender are within the acceptable range, while that of Wade indicated overmaturity. In the multiple harvesting system, seed percentages of all three varieties were within the prescribed range.

In a previous paper, ${ }^{6}$ a tendency to a second flowering was reported in variety Contender during March, 1972-73, yielding at the rate of 7,847 
$\mathrm{kg} / \mathrm{ha}$ in the last picking. This tendency was not observed during the present study.

The results herein reported suggest that the once-over harvesting system should be preferred over the multiple harvesting system. A mechanical harvester should be made available so as to shorten the harvesting period and decrease costs in commercial snap bean production.

\section{RESUMEN}

En la Subestación Experimental Agrícola de Isabela se realizó un experimento con habichuelas tiernas para determinar el efecto de dos sistemas de recolección sobre los rendimientos y el porcentaje de semillas de las variedades Wade, Tendergreen y Contender.

No hubo diferencias significativas entre las tres variedades con respecto a rendimiento al cosecharse por uno u otro sistema.

En el sistema de pases múltiples, dependiendo de la variedad, hay pases en los que se obtienen rendimientos comerciales tan bajos que no amerita efectuarlos. Esto reduciría los costos de producción.

Es preferible utilizar el sistema de recolección de un solo pase con una cosechadora mecánica, ya que así se acorta el período de cosecha y se reducen los costos de producción. 